\title{
Phillips Curve: The Greek Case
}

\author{
PANAGIOTIS LIARGOVAS \& MARIOS PSYCHALIS \\ University of Peloponnese, Tripoli, Greece \\ Email: liargova@uop.gr
}

One of the most important problems facing Greece is the long-term and high-level unemployment rate. The Economic Adjustment Programmes (EAPs) focused on the supply side of the economy, aiming at the adjustment of prices and wages, draw on the classical economic model, as it is widely accepted that internal devaluation policies keep inflation low. This article attempts to examine whether the Keynesian theory and the Phillips Curve, which shows the relationship between unemployment and inflation, apply in the case of the Greek economy. We use descriptive statistics, ordinary least squares (OLS) and VAR Analysis to examine the relationship between the variables. According to the results, there is a negative correlation between unemployment and inflation in Greece, thus confirming the Phillips Curve hypothesis. Finally, results show that unemployment is less dependent on inflation compared with the past, and there are numerous other decisive factors affecting unemployment.

\section{Introduction}

The General Theory was written in 1936 as a response to the human tragedy caused by the Great Depression, with Keynes prescribing a number of measures that governments should undertake to provide economic stability (Sangkuhl 2015). Keynes' burden was to undermine what he termed the 'classical dichotomy' and the 'classical model' in which permanent unemployment is not possible (Evans-Pritchard 1985) and where money was a veil, playing no role in determining output and employment (Johnson et al. 2001). Additionally, he introduced the Keynesian expenditure-based model (Ferguson 2013). Keynes and Say held similar views on several key issues, such as the possibility of aggregate-demand deficiency, the role of money in the economy and government intervention (Béraud and Numa 2019). Keynes propounded that the level of employment in the short run is dependent on the aggregate effective demand of products and services (Keynes, 1936), which is a theory in contrast to the monetarist theory, suggesting that full employment and price stability are not conflicting policy objectives (Friedman 1968).

In the new Keynesian model, the connection between the unemployment rate and the inflation rate is driven by the Phillips curve (Farmer and Nicolò 2018). The 
Phillips curve approach examines the relationship between inflation and unemployment (Phillips 1958), with some studies having confirmed the relationship between inflation and unemployment in Greece (Dritsaki and Dritsaki 2012) and in other countries too (Bildirici and Sonustun 2018). According to research, the relationship between unemployment and inflation is negative and significant in the euro area. Furthermore, nominal wage growth responds strongly to unemployment across labour markets in the monetary union, since one unit increase in the unemployment rate reduces nominal wages by $0.3 \%$ (Levy 2019), with the impact of the output gap on core inflation being significant, but not large (Montoya and Döhring 2011). Research supports that a permanent increase in money growth leads to a permanent increase in the inflation rate and a permanent decrease in the level of unemployment (Graham and Snower 2002; Coibion et al. 2019).

It has been argued that the same relationship between inflation and unemployment applies also between wages and unemployment (Wage Phillips Curve). Nominal wage growth and unemployment are negatively correlated (Galí 2011), even though some economists support the decline in Phillips curve slope coefficient and the shrinking role of lagged price inflation in the determination of wage inflation (Galì and Gambetti, 2018). Other economists support that only inflation correlates with unemployment, whereas wages do not (Bierens and Broersma 1993). It is supported that there is a response of interest rates to announcements of unexpected changes in the unemployment rate, with the natural rate of unemployment being at 5.9\% (Prag 1994). Finally, Samuelson and Solow offer a trade-off view but are very sceptical about the long-run stability of the curve (Schwarzer 2013).

Well-anchored expectations have contributed to enhancing the effectiveness of monetary policy and assist the economic recovery (ECB 2011). It is supported that combining inflation forecasts from many models yields more accurate forecasts than those of any specific model (Altavilla and Ciccarelli 2007), while there is evidence of a high degree of dispersion across models (Altavilla and Ciccarelli 2009). On the other hand, measures such as one-off moves in labour market slack are unlikely to be predictive of changes in trend inflation (Cecchetti et al. 2017). Moreover, Blanchard supports that inflation expectations have become steadily more anchored (Blanchard 2016), and in emerging markets they have become more strongly anchored over time (Sousa and Yetman 2016). Finally, first-hand empirical evidence suggests that inflation expectations of households and firms affect their actions but the underlying mechanisms remain unclear, especially for firms (Coibion et al. 2020).

The breakdown of the Phillips curve occurred in the mid-1970s, when the predicted negative relation between inflation and unemployment turned out to be utterly wrong (Gordon 2013), with different interpretations having been expressed about the function of the curve (Gordon 2010) and many economists pinpointing the failures of the Phillips curve (Hebert 1981). Furthermore, it has been argued that the wage and price adjustments in Greece were similar to those in Germany, Australia and Latvia (Belke and Gros 2018), which means that the classical model works effectively. In other words, some economists support that there is only one rate of unemployment compatible with steady inflation - a 'natural rate' (Tobin 1995) - as well as that the 
relation between inflation and unemployment could be more than coincidental (Friedman 1977), with a strict inflation policy not having a large impact on the unemployment volatility (Campolmi and Gnocchi 2016), whereas other economists support that that there is no clear long-run trade-off between inflation and the unemployment rate (Benati 2015) and that the Phillips curve relationship has weakened, with the curve becoming flatter (Occhino 2019). Finally, it is mentioned that the Phillips curve slope is heterogeneous across countries and the slope has not changed significantly since the global financial crisis (Hindrayanto et al. 2019).

This article is structured as follows: Section 2 discusses the modern literature about the Phillips curve, while Section 3 investigates the economic policy in Greece during the crisis. Section 4 presents the methodology used while the subsequent section describes the data and makes the estimations. Section 6 presents the empirical results and, finally, Section 7 offers some concluding remarks.

\section{Modern Literature about the Phillips Curve}

Recent research shows that fluctuations in core inflation could be explained by expected inflation, the output gap and the pass-through of movements in headline inflation (Ball and Mazumder 2020), while many economists and organizations support that the Phillips Curve has flattened or even disappeared (Dotsey et al. 2017; IMF 2013). More specifically, economists support that the flattening is evident in the baseline 'structural' new-Keynesian Phillips curve (Kuttner and Robinson 2010), while results do not lend support to the view that the flattening of the Phillips curve is due to globalization (Gaiotti 2010).

In addition, researchers support that inflation expectations have been fully 'shock-anchored' since the 1980s (Ball and Mazumder 2011). In other words, they support that the effect of unemployment on inflation, for a given level of expected inflation, decreased until the early 1990s (Blanchard et al. 2015), but the US Phillips curve is alive (Gordon 2013).

Furthermore, economists suggest that a simple rule with an explicit inflation goal could serve as a useful benchmark for avoiding the recurrence of the Great Inflation (Levin and Taylor 2013).

In addition, a group of economists support that inflation follows a seemingly exogenous process, unrelated to measures of slack (Stock and Watson 2007; Forbes et al. 2017) while NAIRU forecasts are not accurate (Atkeson and Ohanian 2001). In the same way, a recent study supports that a large set of Phillips curve models cannot account for the weakness in underlying inflation between mid-2017 and 2019 (ECB 2019).

Regarding the ECB, it adopted a package of mutually reinforcing monetary policy measures during the crisis, such as pushing the policy rate into negative territory, forward guidance on the future policy path, asset purchase programmes (APPs), targeted longer-term refinancing operations (TLTROs), and quantitative easing (QE), in order to boost the European economy's growth (Lane 2019) and reduce 
unemployment, although these monetary measures led to a low economic recovery (Vamvakidis 2015), with the monetary policy effectiveness being dependent on countries' financial, fiscal and market structure (Filiz Baştürk 2013). In addition, economists support that more research is needed on the transmission of negative rates and their financial stability repercussions (Beyer et al. 2017). Monetary easing policy measures, such as the QE, help countries to meet their debt service obligations, but were not adopted in a timely manner, thus they had limited effects on inflation, GDP and sovereign spreads (Driffill 2016). Moreover, the ECB could take on the crucial role as a lender of last resort in order to reduce the economic fragility of the eurozone (De Grauwe 2012) and place equal emphasis on the inflation objective compared with the financial stability objective (De Grauwe and Gros 2009), since the contractionary monetary policy followed by the ECB ignited the economic crisis (Jensen 2016). Furthermore, there was a deviation between the monetary policy goals and the developments in prices, interest rates and economic growth (Rodríguez et al. 2016). Finally, enhanced forms of forward guidance, which comprise negative policy rates, a large asset purchase programme and targeted long-term loans to banks, could help the EMU to halt persistent disinflation in the post-crisis era (Rostagno et al. 2019), while unconventional monetary policy measures are effective in mitigating the downside risks to price stability (Ciccarelli and Osbat 2017).

\section{The Economic Policy in Greece during the Crisis}

The fiscal policy followed by Greece over the economic crisis years was restrictive (Monokroussos 2015; Papadamou and Tzivinikos 2017), resulting in a widening recession and a rise in unemployment (Gechert and Rannenberg 2015), since high debt levels reduced the government's ability to use public expenditure in order to stabilize the economy (Papadimos 2011), for this reason was called on to provide assistance to the financial sector (Caruso et al. 2019). The banking crisis and the increase in non-performing-loans (NPLs), in turn, had additional negative effects on unemployment and inflation (Mazreku et al. 2018).

A primary goal of the EAPs was fostering price competitiveness, through an improved current account balance (Hazakis 2017) and lower unit labour costs (Ioannides and Pissarides 2015), and balancing twin deficits (Gibson et al. 2012), without any emphasis being placed on the non-wage cost, which is a crucial international trade factor (Athanasoglou and Bardakas 2010). According to the perspective of the EAPs, the Greek economy's problem was mainly a supply-side problem and, as a result, the promoted reforms focused on wage-cost reduction measures and structural changes in the labour relations and the product and service market (Bruno 1982). Price competitiveness was considered a key goal for achieving economic progress and improving balance of payment (Bobeica et al. 2016). Added to that, Greece faced deflation during the crisis, which put additional pressure on unemployment (Anastasatos and Stamatiou 2014; Karanasos et al. 2017). In addition, it is argued that some reforms set conflicting objectives, which increases 
unemployment (Liargovas and Psychalis 2019) and underlined the existence of a Wage Phillips Curve (Orlandi et al. 2018).

By contrast, the related literature argues that both the current account balance (Collignon and Esposito 2013) and unit labour costs (Felipe and Kumar 2011) are not competitiveness indicators. Moreover, during a recession period, a business-cycle related domestic demand increase may have a bigger contribution to economic growth than an emphasis on the current account balance improvement (Comunale and Hesse 2014), whereas the adoption of austerity measures may lead to a slower economic growth (Bianchi et al. 2019). Furthermore, it is noted that Greek enterprises tried to address the demand reduction problem through wage cuts (Kosma et al. 2017), with the internal devaluation not leading to a competitiveness boost (Passas and Pierros 2017), since the EAPs do not produce permanent results in terms of promoting exports (Noorbakhsh and Paloni 1998).

Additionally, both supply and demand problems appear in the case of the Greek economy. The supply problems have been present since 1981, whereas the demand problems were caused later by the austerity and wage cuts (Ioannides and Pissarides 2015).

Finally, Greece seems to keep a stable relationship with debt crises, having gone bankrupt four times since 1829 (Reinhart and Rogoff 2011), in addition Greece held the least successful of the euro periphery fiscal devaluation programmes (Petroulakis 2017).

\section{Methodology}

Descriptive statistics, ordinary least squares (OLS) and VAR analysis are employed to examine the relationships between unemployment, as an independent variable, and inflation, as an independent variable, so as to answer the research question. Descriptive statistics are employed to offer an overview and illustrate the development of the indicators and relationships under examination. Regression analysis is employed to examine the correlation between the variables under examination in the group of countries, Greece, Spain, France, Italy, Germany and Portugal. The correlation coefficient between the variables reflects the degree of linear relationship between two variables. The ordinary least squares method is employed to examine the relationships between the variables under examination, monitoring whether independent variables affect dependent variables. VAR analysis was employed for forecasting systems of interrelated time series, as causality tests refers to the ability of one variable to predict or cause the other (Asteriou and Hall 2006). Finally, all these tools offer a complete overview of the variables under examination.

\section{Data and Estimations}

Figure 1 shows that there was a dramatic inflation fall during crisis from $5 \%$ to $-1.5 \%$, and, respectively, an unemployment increase, from $7 \%$ to $27 \%$. Furthermore, Figure 2 shows inflation is negatively correlated with unemployment (Mastromatteo and Rossi 


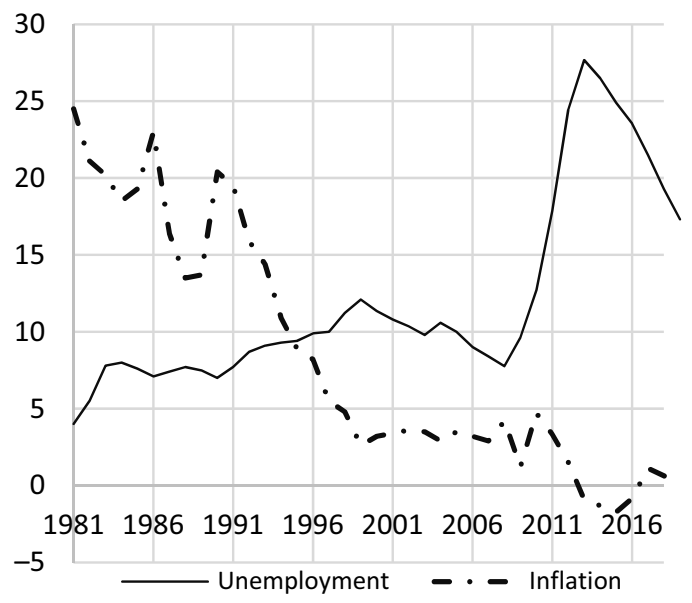

Figure 1. Unemployment rate and inflation rate.

Source: Bank of Greece

2015), since a decrease in inflation appears to be associated with an increase in unemployment (Frangakis 2015), with the correlation coefficient being -0.83 and the equation expressing the relationship between these two variables being: $y=-0.55 x+16.57$, i.e. an increase in inflation by 1 percentage point decreases unemployment by 0.55 percentage points. Based on Figure 3, in Greece, the Phillips curve kept flattening during the 1980s, 1990s and 2000s; however, during the last decade its slope steepened sharply, without confirming the Phillips curve hypothesis. Likewise, a negative correlation between inflation and unemployment is also observed in France, Spain, Portugal and Italy, as illustrated in Figure 4, with the exception of Germany which features an almost flat curve.

Table 1 shows that a negative correlation coefficient between inflation and unemployment does not only appear in the case of Greece, but also in the cases of France, Italy, Portugal, Spain and Austria. Moreover, inflation appears to affect unemployment more severely in Spain, with other studies reaching similar conclusions (Hindrayanto et al. 2019). On the other hand, it seems that inflation is not really correlated to unemployment in Germany.

Table 2 illustrates the relationship between the dependent variable (i.e. unemployment), and the independent variables (i.e. inflation, unit labour cost, current account balance and long-term borrowing rate). According to the regression, an increase in inflation by 1 basis point decreases unemployment by 1.14 percentage points, which confirms the negative correlation between unemployment and inflation. On the other hand, an increase of the current account balance by 1 basis point increases unemployment by 0.67 percentage points, while an increase in the unit labour cost by 1 percentage point decreases unemployment by 0.35 percentage points. The inverse relationship between Current Account Balance and Unit Labour Cost to unemployment, compared with prevailing literature (Salop and Spitäller 1980; Rebitzer 1988; Britton 1989), is explained by the economic model previously applied in Greece and 


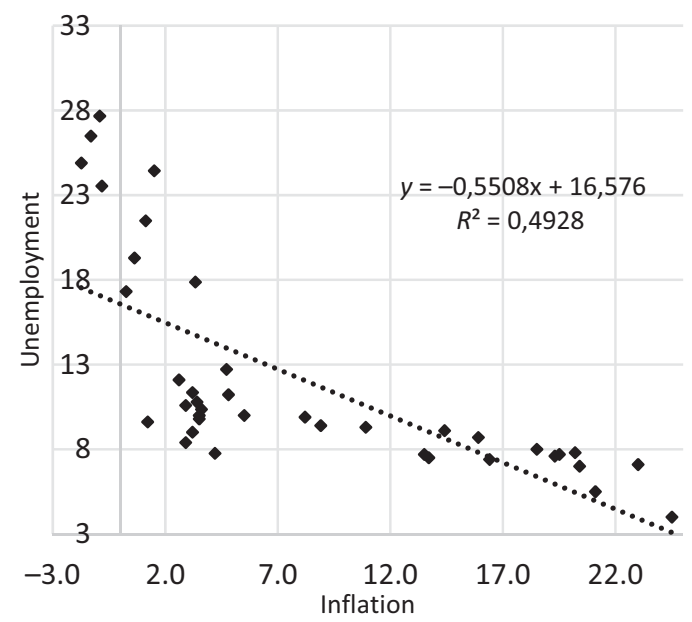

Figure 2. Unemployment rate and inflation rate in Greece. Source: OECD

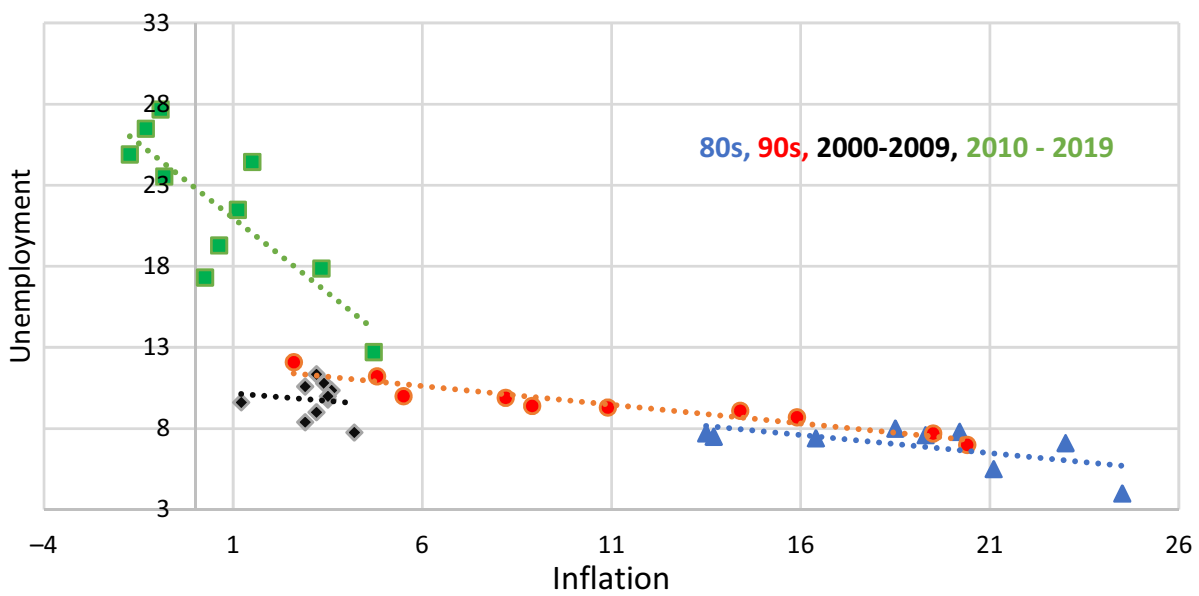

Figure 3. Unemployment rate and inflation rate in Greece during in 1980s, 1990s, 2000s and 2010s (to view this figure in colour please see the online version of this journal).

Source: OECD

other Southern European countries, as the constant twin deficits in state budget and current account balance restricted competitiveness, which led to increased unit labour cost, while jobs were linked to consuming and government spending (Busch et al. 2011). Finally, an increase in the long-term borrowing rate by 1 percentage point increases unemployment by 0.35 percentage points. This relation is also confirmed by the literature (Bierens and Broersma 1993; Feldmann 2013).

The negative correlation between unemployment and inflation is also confirmed by the multivariate regressions performed for Italy, Spain, Portugal and Germany, 


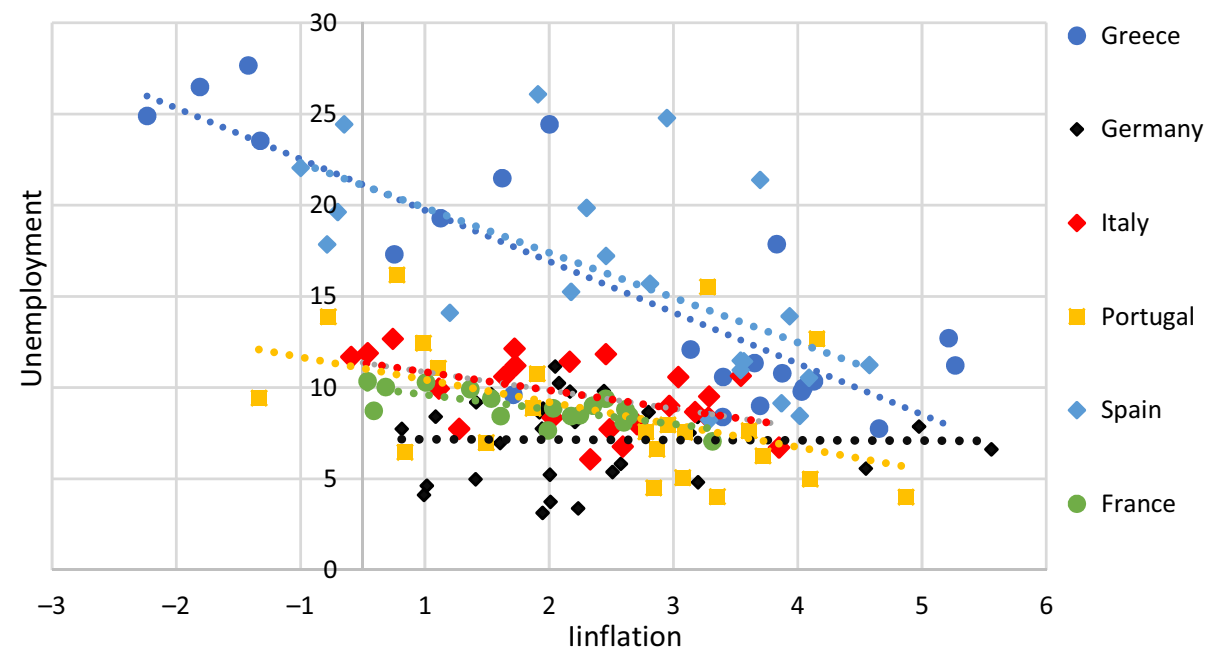

Figure 4. Unemployment rate and inflation rate in Greece, Spain, Portugal, Germany, Italy and France (to view this figure in colour please see the online version of this journal).

Source: OECD

Table 1. Unemployment and inflation correlation and the linear equation.

\begin{tabular}{lcc}
\hline \hline Country & Unemployment and inflation correlation & Linear equation \\
\hline Greece & -0.83472 & $y=-0.5508 x+16.576$ \\
Germany & -0.00935 & $y=-0.0186 x+7.1719$ \\
France & -0.72249 & $y=-0.8076 x+10.017$ \\
Italy & -0.50429 & $y=-1.0076 x+11.363$ \\
Spain & -0.627 & $y=-2.4598 x+21.083$ \\
Portugal & -0.47202 & $y=-1.2345 x+11.05$ \\
Austria & -0.34401 & $y=-0.275 x+5.4278$ \\
\hline \hline
\end{tabular}

which produced similar results as for Greece for all indicators, as illustrated in multivariate Tables 3 to 6 .

Contrary to the above, Table 7 shows that during 2004-2018, unemployment in Greece was slightly affected by past inflation values, while - apart from the model's internal factors - other external factors significantly affect the unemployment rate. Therefore, based on VAR Analysis 1, one can conclude that there is a positive, yet weak, relationship between unemployment and past inflation values. In addition, VAR Analyses 2 and 3, which study two different time periods in Greece, reveal a positive relationship between unemployment and past inflation values, for most values, although inflation does not significantly affect unemployment, while in both cases numerous external factors, besides inflation, affect unemployment. It is noted that the remaining variables have the same trend in Multivariate VAR as in 
Table 2. Multivariate regression for Greece.

Dependent variable: Unemployment rate in Greece

Sample: 2002-2018. Included observations: 17 after adjustments

\begin{tabular}{lcccr}
\hline Variable & Coefficient & Std. error & t-statistic & Prob \\
\hline GRC inflation & -1.14 & 0.31 & -3.6 & 0.00 \\
GRC ULC & -0.35 & 0.13 & -2.66 & 0.02 \\
GRC CAB & 0.67 & 0.13 & 5.10 & 0.00 \\
GRC interest & 0.35 & 0.09 & 3.74 & 0.00 \\
$C$ & 20.76 & 1.09 & 18.94 & 0.00 \\
$R$-squared & 0.96 & Mean dependent var & 16.11 \\
Adj. $R$-squared & 0.95 & SD dependent var & 7.33 \\
SE of regression & 1.53 & Akaike info criterion & 3.93 \\
Sum squared resid & 28.29 & Schwarz criterion & 4.18 \\
F-statistic & 88.15 & Durbin-Watson stat & 2.29 \\
Prob (F-statistic) & 0.00 & & & \\
\hline \hline
\end{tabular}

Table 3. Multivariate regression for Portugal.

Dependent variable: Unemployment rate in Spain

Sample: 1999-2018. Included observations: 20 after adjustments

\begin{tabular}{lcccr}
\hline Variable & Coefficient & Std. error & t-statistic & Prob \\
\hline SPA inflation & -1.41 & 0.47 & -2.95 & 0.00 \\
SPA ULC & -0.87 & 0.34 & -2.51 & 0.02 \\
SPA CAB & 0.70 & 0.17 & 3.94 & 0.00 \\
SPA interest & 1.41 & 0.42 & 3.29 & 0.00 \\
$C$ & 16.59 & 1.37 & 12.05 & 0.00 \\
$R$-squared & 0.91 & Mean dependent var & 15.98 \\
Adj. $R$-squared & 0.89 & SD dependent var & 5.79 \\
SE of regression & 1.87 & Akaike info criterion & 4.30 \\
Sum squared resid & 52.60 & Schwarz criterion & 4.55 \\
F-statistic & 41.66 & Durbin-Watson stat & 1.57 \\
Prob (F-statistic) & 0.00 & & & \\
\hline
\end{tabular}

Multivariate Regression, while inflation is the only variable differentiating between Multivariate Regression and Multivariate VAR.

\section{Results}

During the financial crisis, inflation fell while unemployment increased. The results indicate that there is a negative correlation between inflation and unemployment, since an inflation decrease leads to an unemployment increase, thus confirming the Phillips curve hypothesis in Greece, as part of literature supports (Dritsaki and Dritsaki 2012; Dritsakis and Stamatiou 2016; Juselius and Dimelis 2018), while 
Table 4. Multivariate regression for Spain.

Dependent variable: Unemployment rate in Portugal Sample: 1998-2018. Included observations: 21 after adjustments

\begin{tabular}{lcccc}
\hline Variable & Coefficient & Std. error & t-statistic & Prob \\
\hline POR inflation & -1.30 & 0.30 & -4.26 & 0.00 \\
POR ULC & -0.64 & 0.22 & -2.88 & 0.01 \\
POR CAB & 0.20 & 0.08 & 2.39 & 0.02 \\
POR interest & 0.62 & 0.20 & 2.98 & 0.00 \\
$C$ & 10.48 & 1.03 & 10.09 & 0.00 \\
$R$-squared & 0.88 & Mean dependent var & 8.76 \\
Adj. $R$-squared & 0.85 & SD dependent var & 3.71 \\
SE of regression & 1.43 & Akaike info criterion & 3.76 \\
Sum squared resid & 32.94 & Schwarz criterion & 4.01 \\
F-statistic & 29.45 & Durbin-Watson stat & 1.61 \\
Prob (F-statistic) & 0.00 & & \\
\hline \hline
\end{tabular}

Table 5. Multivariate regression for Italy.

Dependent variable: Unemployment rate in Italy

Sample: 1998-2018. Included observations: 21 after adjustments

\begin{tabular}{lcccc}
\hline Variable & Coefficient & Std. error & t-statistic & Prob \\
\hline ITA inflation & -1.45 & 0.33 & -4.34 & 0.00 \\
ITA CAB & 0.96 & 0.11 & 8.21 & 0.00 \\
ITA interest & 1.17 & 0.28 & 4.07 & 0.00 \\
$C$ & 7.49 & 0.81 & 9.13 & 0.00 \\
$R$-squared & 0.85 & Mean dependent var & 9.60 \\
Adj. $R$-squared & 0.82 & SD dependent var & 2.02 \\
SE of regression & 0.84 & Akaike info criterion & 2.66 \\
Sum squared resid & 12.02 & Schwarz criterion & 2.86 \\
F-statistic & 33.03 & Durbin-Watson stat & 2.21 \\
Prob (F-statistic) & 0.00 & & \\
\hline
\end{tabular}

the slope of the curve has substantially flattened. It is noted that the negative correlation between unemployment and inflation is also documented in other EMU countries, both by literature and empirical evidence. Furthermore, in Greece, results show that dependence of unemployment on inflation has decreased compared with past years. The negative correlation between unemployment and inflation is further documented by the Multivariate Regression, as an increase in inflation by $1 \%$ seems to decrease unemployment by 1.14 percentage points, while similar results are produced for other EMU countries too. On the contrary, the VAR analysis indicates that an increase in inflations tends to cause an increase in unemployment. This relationship was consistent in different time periods (1987-1999 and 2006-2019). Consequently, despite Multivariate Regressions and Descriptive Statistics Analysis indicating a 
Table 6. Multivariate regression for Germany.

Dependent Variable: Unemployment rate in Germany

Sample: 1992-2018. Included observations: 27 after adjustments

\begin{tabular}{lcccc}
\hline Variable & Coefficient & Std. error & t-statistic & Prob \\
\hline GER inflation & -0.75 & 0.28 & -2.61 & 0.01 \\
GER ULC & -0.31 & 0.11 & -2.72 & 0.01 \\
GER CAB & 0.29 & 0.12 & 2.28 & 0.03 \\
GER interest & 1.30 & 0.24 & 5.25 & 0.00 \\
$C$ & 3.15 & 1.25 & 2.51 & 0.01 \\
$R$-squared & 0.74 & Mean dependent var & 7.43 \\
Adj. $R$-squared & 0.70 & SD dependent var & 2.11 \\
SE of regression & 1.15 & Akaike info criterion & 3.28 \\
Sum squared resid & 29.25 & Schwarz criterion & 3.52 \\
F-statistic & 16.40 & Durbin-Watson stat & 1.24 \\
Prob (F-statistic) & 0.00 & & & \\
\hline \hline
\end{tabular}

Table 7. Vector autoregression estimates.

\begin{tabular}{|c|c|c|c|c|c|c|c|}
\hline \multicolumn{2}{|c|}{ Vector Autoregression Estimates 1} & \multicolumn{3}{|c|}{ Vector Autoregression Estimates 2} & \multicolumn{3}{|c|}{ Vector Autoregression Estimates 3} \\
\hline \multicolumn{2}{|c|}{ Vector Autoregression Estimates } & \multicolumn{3}{|c|}{ Vector Autoregression Estimates } & \multicolumn{3}{|c|}{ Vector Autoregression Estimates } \\
\hline \multicolumn{2}{|c|}{ Sample (adjusted): 2004- 2018} & \multicolumn{3}{|c|}{ Sample (adjusted): 1987 - 1999} & \multicolumn{3}{|c|}{ Sample (adjusted): 2006-2019 } \\
\hline \multicolumn{2}{|c|}{ Included observations 15 after adjustment } & \multicolumn{3}{|c|}{ Included observations 13 after adjustments } & \multicolumn{3}{|c|}{ Included observations 14 after adjustments } \\
\hline \multicolumn{2}{|c|}{ standard errors in ( ) \& t-statistics in \{\}} & \multicolumn{3}{|c|}{ standard errors in ( ) \& t-statistics in \{\}} & \multicolumn{3}{|c|}{ standard errors in ( ) \& t-statistics in \{\}} \\
\hline & GRC UNEMPL & & GRC UNEMPL & GRC INFLAT & & GRC UNEMPL & GRC INFLAT \\
\hline GRC UNEMPL $(-1)$ & $2,96(0,55)\{5,35\}$ & GRC UNEMPL (-1) & $0,44(0,50)\{0,87\}$ & $-4,31(3,26)\{-1,32\}$ & GRC UNEMPL (-1) & $2,76(0,38)\{7,12\}$ & $0,20(0,37)\{0,55\}$ \\
\hline GRC UNEMPL (-2) & $-0,75(0,42)\{-1,75\}$ & GRC UNEMPL (-2) & $1,05(0,64)\{1,63\}$ & $-2,97(4,13)\{0,71\}$ & GRC UNEMPL (-2) & $-2,42(0,60)\{-4,00\}$ & $-0,63(0,57)\{-1,09\}$ \\
\hline $\operatorname{GRC} \operatorname{INFL}(-1)$ & $0,69(0,33)\{2,06\}$ & GRC UNEMPL (-4) & $0,08(1,16)\{0,07\}$ & $-7,84(7,46)\{-1,05\}$ & GRC UNEMPL (-4) & $1,43(0,86)\{1,65\}$ & $-0,35(0,82)\{-0,42\}$ \\
\hline GRCINFL (-2) & $0,47(0,38)\{1,22\}$ & GRC UNEMPL (-5) & $0,00(0,51)\{0,00\}$ & $-0,73(3,29)\{-0,22\}$ & GRC UNEMPL (-5) & $-0,39(0,76)\{-051\}$ & $0,32(0,72)\{0,45\}$ \\
\hline GRC ULC (-1) & $0,23(0,16)\{1,44\}$ & GRC UNEMPL (-6) & $0,24(0,53)\{0,45\}$ & $-2,85(3,43)\{-0,82\}$ & GRC UNEMPL (-6) & $0,07(0,60)\{0,11\}$ & $0,48(0,57)\{0,84\}$ \\
\hline GRC ULC (-2) & $0,36(0,13)\{2,67\}$ & GRC INTEREST $(-1)$ & $0,05(0,13)\{0,41\}$ & $-0,83(0,86)\{-0,96\}$ & GRC INTEREST (-1) & $0,65(0,53)\{1,23\}$ & $-0,73(0,50)\{-1,44\}$ \\
\hline GRC INTEREST (-1) & $-0,25(0,16)\{-1,53\}$ & GRC INTEREST (-2) & $0,10(0,10)\{1,09\}$ & $-0,95(0,64)\{-1,48\}$ & GRC INTEREST (-2) & $-0,26(0,54)\{-0,49\}$ & $-0,60(0,51)\{-1,44\}$ \\
\hline GRC INTEREST (-2) & $-0,49(0,14)\{-3,53\}$ & GRC INTEREST (-4) & $-0,12(0,13)\{-0,97\}$ & $-0,86(0,84)\{-1,03\}$ & GRC INTEREST (-4) & $1,82(0,77)\{2,34\}$ & $0,55(0,74)\{0,74\}$ \\
\hline $\operatorname{GRC~CAB~}(-1)$ & $-0,64(0,34)\{-1,87\}$ & GRC INTEREST (-5) & $0,00(0,07)\{-0,07\}$ & $-0,21(0,48)\{-0,45\}$ & GRC INTEREST (-5) & $0,44(0,80)\{0,55\}$ & $0,69(0,76)\{0,90\}$ \\
\hline $\operatorname{GRCCAB}(-2)$ & $-0,13(0,27)\{-0,49\}$ & GRC INTEREST (-6) & $0,02(0,08)\{0,27\}$ & $-0,05(0,57)\{-0,10\}$ & GRC INTEREST (-6) & $-1,17(0,81)\{-1,42\}$ & $0,56(0,78)\{0,72\}$ \\
\hline $\mathrm{C}$ & $-22,42(7,42)\{-3,01\}$ & $\mathrm{C}$ & $-6,74(18,33)\{-0,36\}$ & $207,70(117,53)\{1,76\}$ & \begin{tabular}{|c|}
$\mathrm{C}$ \\
\end{tabular} & $-8,84(11,25)\{-0,78\}$ & $0,32(10,72)\{0,03\}$ \\
\hline R-squared & 0,99 & R-squared & 0,99 & 0,97 & R-squared & 0,99 & 0,91 \\
\hline Adj. R-squared & 0,98 & Adj. R-squared & 0,95 & 0,85 & Adj. R-squared & 0,96 & 0,63 \\
\hline Sum sq. resids & 3,73 & Sum sq. resids & 0,22 & 9,22 & Sum sq. resids & 5,31 & 4,82 \\
\hline S.E equation & 0,96 & S.E equation & 0,33 & 2,14 & S.E equation & 1,33 & 1,26 \\
\hline F-statistic & 82,83 & F-statistic & 25,52 & 8,03 & F- statistic & 37,81 & 3,27 \\
\hline Log Likehood & $-10,85$ & Log Likehood & 7,93 & $-16,21$ & Log Likehood & $-13,08$ & $-12,40$ \\
\hline Akaike & 2,91 & Akaike & 0,47 & 4,18 & Akaike & 3,44 & 3,34 \\
\hline Schwarz SC & 3,43 & Schwarz SC & 0,94 & 4,66 & Schwarz SC & 3,94 & 3,84 \\
\hline Mean dependent & 16,91 & Mean dependent & 9,00 & 11,90 & Mean dependent & 17,89 & 1,30 \\
\hline S.D dependent & 7,44 & S.D dependent & 1,55 & 5,26 & S.D dependent & 7,20 & 2,10 \\
\hline
\end{tabular}

negative correlation between unemployment and inflation, and in certain cases a strong negative correlation, confirming the Phillips Curve hypothesis, VAR Analysis indicates that past inflation values tend to be positively correlated to unemployment, therefore confirming classical economists.

\section{Conclusion}

The conclusions drawn are not clear. On the one hand, there are some findings that confirm the Keynesian theory, and more specifically the true application of the 
Phillips curve on the relationship between inflation and unemployment, since a decrease in inflation leads to an increase in unemployment. Therefore, what is confirmed in the current article is the views of that part of the literature holding that there is no clear prevalence of Keynesians over Classicals, or vice versa, with both schools of economic thought being live and co-examined (Dumenil and Levy 1997; Chaudhry et al. 2014). However, inflation can only explain a small fraction of unemployment, as new factors affecting unemployment have arisen and there is evidence confirming the negative relationship between unemployment and inflation. In conclusion, because of the ECB's monetary policy, inflation tends to have less and less impact on unemployment, but without cancelling out the Phillips Curve hypothesis. In the future, more detailed analysis could be done. For example, an impulse response shock analysis could be carried out in order to examine the effect of inflation on unemployment.

\section{References}

Altavilla C and Ciccarelli M (2007) Inflation Forecasts, Monetary Policy and Unemployment Dynamics Evidence from the US and the Euro Area. Frankfurt: ECB. Retrieved from https://www.ecb.europa.eu/pub/pdf/scpwps/ecbwp725.pdf

Altavilla C and Ciccarelli M (2009) The Effects of Monetary Policy on Unemployment Dynamics under Model Uncertainty Evidence from the US and the Euro Area. Frankfurt: ECB. Retrieved from https://www.ecb.europa.eu/ pub/pdf/scpwps/ecbwp1089.pdf

Anastasatos T and Stamatiou T (2014) Is Deflation a Risk for Greece? Athens: Eurobank Research. Retrieved from https://www.eurobank.gr/Uploads/Reports/ ECONOMYMARKETS_APRIL2014\%20MAY\%20UPDATE.pdf

Asteriou D and Hall S (2006) Applied Econometrics: A Modern Approach Using EViews and Microfit. London: Palgrave Macmillan.

Athanasoglou PP and Bardakas I (2010) New trade theory, non-price competitiveness and export performance. Economic Modelling 1, 217-228. doi: 10.1016/j. econmod.2009.09.002

Atkeson A and Ohanian L (2001) Are Phillips Curves Useful for Forecasting Inflation? Minneapolis: Federal Reserve Bank of Minneapolis.

Ball L and Mazumder S (2011) Inflation dynamics and the great recession. Brookings Papers on Economic Activity 42(1), 337-405. doi: 10.3386/w17044

Ball L and Mazumder S (2020) A Phillips Curve for the Euro Area. Frankfurt: ECB. Retrieved from https://www.ecb.europa.eu/pub/pdf/scpwps/ecb.wp2354 9f0fd070ff. en.pdf

Belke A and Gros D (2018) Greece and the Troika - lessons from international best practice cases of successful price (and wage) adjustment. European Journal of Comparative Economics 14(2), 177-195. doi: 10.25428/1824-2979/201702-177-195

Benati L (2015) The long-run Phillips curve: a structural VAR investigation. Journal of Monetary Economics 76, 15-28. doi: https://doi.org/10.1016/j.jmoneco.2015.06.007

Béraud A and Numa G (2019) Retrospectives: Lord Keynes and Mr. Say: a proximity of ideas. Journal of Economic Perspectives 33(3), 228-242. doi: 10.1257/jep.33.3.228

Beyer A, Cœuré B and Mendicino C (2017) Foreword - The Crisis, Ten Years After: Lessons Learnt for Monetary and Financial Research. Frankfurt: ECB. doi: https:// doi.org/10.24187/ecostat.2017.494t.1918 
Bianchi F, Comin D, Kung H, Kind T and Matusche A (2019) Slow recoveries through fiscal austerity. ZEW - Leibniz Centre for European Economic Research, 26 February. Retrieved from https://www.econstor.eu/bitstream/10419/200172/1/ 1667903462.pdf

Bierens H and Broersma L (1993) The relation between unemployment and interest rate. Econometric Reviews 12(2), 217-256. doi: 10.1080/07474939308800262

Bildirici M and Sonustun F (2018) Backward bending structure of Phillips Curve in Japan, France, Turkey and the U.S.A. Economic Research-Ekonomska Istraživanja 31(1), 537-549. doi: https://doi.org/10.1080/1331677X.2018.1441046

Blanchard O (2016) The Phillips curve: back to the "60s? American Economic Review 106(5), 31-34. doi: 10.1257/aer.p20161003

Blanchard O, Cerutti E and Summers L (2015) Inflation and Activity - Two Explorations and their Monetary Policy Implications. Washington: IMF. Retrieved from www.imf.org/external/pubs/ft/wp/2015/wp15230.pdf

Bobeica E, Christodoulopoulou S and Tkačevs $\mathbf{O}$ (2016) The Role of Price and Cost Competitiveness for Intra- and Extra-Euro Area Trade of Euro Area Countries. Frankfurt: ECB.

Britton A (1989) Full employment and the balance of payments. In Conquering Unemployment: The Case for Economic Growth. London: Palgrave Macmillan, pp. 186-207.

Bruno M (1982) Adjustment and structural change under supply shocks. Scandinavian Journal of Economics 84(2), 199-221. doi: 10.3386/w0814

Busch B, Grömling M and Matthes J (2011) Current account deficits in Greece, Portugal and Spain - origins and consequences. Intereconomics 46(6), 354-360. Retrieved from www.intereconomics.eu/contents/year/2011/number/6/article/current-account-deficitsin-greece-portugal-and-spain-origins-and-consequences.html

Campolmi A and Gnocchi S (2016) Labor market participation, unemployment and monetary policy. Journal of Monetary Economics 79, 17-29. doi: https://doi.org/ 10.1016/j.jmoneco.2016.03.001

Caruso A, Reichlin L and Ricco G (2019) Financial and fiscal interaction in the Euro area crisis: this time was different. European Economic Review 119, 333-355. doi: https://doi.org/10.1016/j.euroecorev.2019.08.002

Cecchetti S, Feroli M, Hooper P, Kashyap A and Schoenholtz K (2017) Deflating Inflation Expectations: The Implications of Inflation's Simple Dynamics. London: CEPR.

Chaudhry I, Faridi M and Gul E (2014) The Classical-Keynesian Paradigm: Policy Debate in Contemporary Era. Munich: Munich Personal RePEc Archive.

Ciccarelli M and Osbat C (2017) Low Inflation in the Euro Area: Causes and Consequences. Frankfurt: ECB. Retrieved from www.ecb.europa.eu/pub/pdf/ scpops/ecbop181.en.pdf

Coibion O, Gorodnichenko Y and Ulate M (2019) Is inflation just around the corner? The Phillips curve and global inflationary pressures. American Economic Association 109, 465-469. doi: 10.1257/pandp.20191055

Coibion O, Gorodnichenko Y, Kumar S and Pedemonte M (2020) Inflation expectations as a policy tool? Journal of International Economics 124. doi: https://doi. org/10.1016/j.jinteco.2020.103297

Collignon S and Esposito P (2013) Unit Labour Costs and Capital Efficiency in the Euro Area: a New Competitiveness Indicator, 1st Edn. London: Routledge. Retrieved from www.stefancollignon.de/PDF/Chap-2_Unit-labour-Costs-andcapital-Efficiency-in-the-Euro-Area.pdf 
Comunale M and Hesse J (2014) Current Account Imbalances in the Euro Area: Competitiveness or Financial Cycle? Amsterdam: De Nederlandsche Bank NV. Retrieved from www.dnb.nl/en/binaries/Working\%20Paper\%20443_tcm47-313481.pdf

De Grauwe P (2012) The governance of a fragile eurozone. The Australian Economic Review 45(3), 255-268. doi: https://doi.org/10.1111/j.1467-8462.2012.00691.x

De Grauwe P and Gros D (2009) A New Two-Pillar Strategy for the ECB. Munich: CESifo.

Dotsey M, Fujita S and Star T (2017) Do Phillips Curves Conditionally Help to Forecast Inflation? Philadelphia: Federal Reserve Bank of Philadelphia. Retrieved from www. philadelphiafed.org/-/media/research-and-data/publications/working-papers/2017/wp 17-26.pdf

Driffill J (2016) Unconventional monetary policy in the euro zone. Open Economies Review 27(2), 387-404. doi: https://doi.org/10.1007/s11079-016-9393-0

Dritsaki C and Dritsaki M (2012) Inflation, unemployment and the NAIRU in Greece. Procedia Economics and Finance 1, 118-127. doi: https://doi.org/10. 1016/S2212-5671(12)00015-9

Dritsakis N and Stamatiou P (2016) The effects of unemployment on economic growth in Greece. An ARDL bound test approach. Romanian Journal of Economic Forecasting 14(62), 53-69.

Dumenil G and Levy D (1997) Being Keynesian in the Short Term and Classical in the Long Term. The Traverse to Classical Long-Term Equilibrium. Paris: CEPREMAP.

ECB (2011) Inflation Expectations in the Euro Area: a Review of Recent Developments. Frankfurt: ECB. Retrieved from www.ecb.europa.eu/pub/pdf/ other/art1_mb201102en_pp73-86en.pdf

ECB (2019) Drivers of Underlying Inflation in the Euro Area over Time: a Phillips Curve Perspective. Frankfurt: ECB. Retrieved from www.ecb.europa.eu/pub/ economic-bulletin/html/eb201904.en.html\#IDofOverviewes_Eb

Evans-Pritchard J (1985) Keynesian theory of employment. Macroeconomics. London: Palgrave Macmillan, pp. 63-80. doi: https://doi.org/10.1007/978-1349-17926-8_4

Farmer R and Nicolò G (2018) Keynesian economics without the Phillips curve. Journal of Economic Dynamics and Control 89, 137-150. doi: https://doi.org/10. 1016/j.jedc.2018.01.012

Feldmann H (2013) Real interest rate and labor market performance around the world. Southern Economic Journal 79(3), 659-679. doi: https://doi.org/10.4284/ 0038-4038-2011.156

Felipe J and Kumar U (2011) Unit Labor Costs in the Eurozone: The Competitiveness Debate Again. New York: Levy Economics Institute.

Ferguson B (2013) Lectures on John Maynard Keynes' General Theory of Employment, Interest and Money (3): Chapter 3, 'The Principle of Effective Demand'. Guelph: University of Guelph Department of Economics and Finance.

Filiz Baştürk M (2013) Non-standard Monetary Policies Implemented by the European Central Bank after the Financial Crisis. Istanbul: International Istanbul Finance Congress, pp. 81-105. doi: 10.14783/maruoneri.vi.331576

Forbes K, Kirkham L and Theodoridis K (2017) A Trendy Approach to UK Inflation Dynamics. London: Bank of England. doi: http://dx.doi.org/10.2139/ssrn.2990338

Frangakis M (2015) Public debt crisis, austerity and deflation: the case of Greece. Review of Keynesian Economics 3(3), 295-313. doi: https://doi.org/10.4337/roke.2015.03.02

Friedman M (1968) The Role of Monetary Policy. The American Economic Review 58(1), $1-17$. 
Friedman M (1977) Nobel lecture: inflation and unemployment. Journal of Political Economy 85(3), 451-472. doi: https://doi.org/10.1086/260579

Gaiotti E (2010) Has globalization changed the Phillips curve? Firm-level evidence on the effect of activity on prices. International Journal of Central Banking 6(1), 51-84. Retrieved from www.ijcb.org/journal/ijcb10q1a3.htm

Galì J and Gambetti L (2018) Has the U.S. Wage Phillips Curve Flattened? A SemiStructural Exploration. Santiago: Central Bank of Chile.

Galí J (2011) The return of the wage Phillips curve. Journal of the European Economic Association 9(3), 436-461. doi: 10.3386/w15758

Gechert S and Rannenberg A (2015) The costs of Greece's fiscal consolidation. Vierteljahrshefte zur Wirtschaftsforschu 84(3), 47-59. doi: http://dx.doi.org/10. 3790/vjh.84.3.47

Gibson H, Hall S and Tavlas G (2012) The Greek financial crisis: growing imbalances and sovereign spreads. Journal of International Money and Finance 31(3), 498516. doi: https://doi.org/10.1016/j.jimonfin.2011.10.009

Gordon R (2010) The history of the Phillips curve: consensus and bifurcation. Economica 78(309), 10-50. doi: https://doi.org/10.1111/j.1468-0335.2009.00815.x

Gordon R (2013) The Phillips Curve is Alive and Well: Inflation and the NAIRU during the Slow Recovery. Cambridge: National Bureau of Economic Research. Retrieved from www.nber.org/papers/w19390.pdf

Graham L and Snower D (2002) The Return of the Long-run Phillips Curve. London: Centre for Economic Policy Research.

Hazakis K (2017) An institutional proposal for economic adjustment in the euroarea. Sustainable Development, Culture, Traditions 1, 82-100. doi: 10.26341/issn.22414002-2017-1a-8

Hebert R (1981) Failures of the Phillips curve. Creative Science and Technology 5.

Hindrayanto I, Samarina A and Stanga I (2019) Is the Phillips curve still alive? Evidence from the euro area. Economics Letters 174, 149-152. doi: https://doi. org/10.1016/j.econlet.2018.11.021

IMF (2013) The Dog that didn't Bark: has Inflation been Muzzled or was it just Sleeping? Washington: IMF.

Ioannides Y and Pissarides C (2015) Is the Greek crisis one of supply or demand? Brookings Papers on Economic Activity 9, 349-373. Retrieved from www. brookings.edu/wp-content/uploads/2015/09/IoannidesTextFall15BPEA.pdf

Jensen M (2016) A comment on De Grauwe's, 'The legacy of the Eurozone crisis and how to overcome it'. Journal of Empirical Finance 39, 166-168. doi: https://doi. org/10.1016/j.jempfin.2016.07.011

Johnson L, Ley R and Cate T (2001) Keynes' theory of money and his attack on the classical model. International Advances in Economic Research 7(4), 409-418. doi: https://doi.org/10.1007/BF02295770

Juselius K and Dimelis S (2018) The Greek crisis: a story of self-reinforcing feedback mechanisms. Economics 13 September. Retrieved from www.economics-ejournal. org/economics/discussionpapers/2018-65

Karanasos M, Koutroumpis P, Hatgioannides J, Karanassou M and Sala H (2017) The Greek Dra(ch)ma: 5 Years of Austerity. The Three Economists' View and a Comment. London: LSE and Hellenic Observatory.

Keynes J (1936) The General Theory of Employment, Interest, and Money, 1st Edn. London: Palgrave Macmillan.

Kosma H, Papapetrou E, Pavlou G, Tsochatzi C and Zioutou P (2017) Labour Market Adjustment and Labour Market Reforms in Greece during the Crisis: Microeconomic 
Evidence from the Third Wave of the Wage Dynamics Survey. Athens: BoG. Retrieved from www.bankofgreece.gr/Publications/Paper2017227.pdf

Kuttner K and Robinson T (2010) Understanding the flattening Phillips curve. The North American Journal of Economics and Finance 21(2), 110-125. doi: https:// doi.org/10.1016/j.najef.2008.10.003

Lane P (2019) The Phillips Curve at the ECB. Frankfurt: ECB.

Levin A and Taylor J (2013) Falling behind the curve: a positive analysis of stop-start monetary policies and the great inflation. In The Great Inflation: The Rebirth of Modern Central Banking. Chicago: University of Chicago Press, p. 544.

Levy A (2019) The Euro Area Phillips Curve: Identification with Regional Data. Massachusetts: MIT Economics Department.

Liargovas P and Psychalis M (2019) Do economic adjustment programmes set conflicting objectives? The case of Greece. Theoretical Economics Letters 9, 3065 3087. doi: https://doi.org/10.4236/tel.2019.98188

Mastromatteo G and Rossi S (2015) The economics of deflation in the euro area: a critique of fiscal austerity. Review of Keynesian Economics 3(3), 336-350. doi: https://doi.org/10.4337/roke.2015.03.04

Mazreku I, Morina F, Misiri V, Spiteri J and Grima S (2018) Determinants of the level of non-performing loans in commercial banks of transition countries. European Research Studies Journal 11(3), 3-13. Retrieved from www.ersj.eu/ dmdocuments/2018_XXI_3_1.pdf

Monokroussos P (2015) The Macroeconomic Costs of Fiscal Adjustment in Greece. Athens: Eurobank Research.

Montoya L and Döhring B (2011) The Improbable Renaissance of the Phillips Curve: The Crisis and Euro Area Inflation Dynamics. Brussels: European Commission.

Noorbakhsh F and Paloni A (1998) Structural adjustment programmes and export supply response. Journal of International Development 10(4), pp. 555-573. doi: https://doi. org/10.1002/(SICI)1099-1328(199806)10:4<555:AID-JID545>3.0.CO;2-P

Occhino F (2019) The Flattening of the Phillips Curve: Policy Implications Depend on the Cause. Cleveland: Federal Reserve Bank of Cleveland. doi: 10.26509/frbc-ec201911

Orlandi F, Roeger W and Thum-Thyse A (2018) The Return of the European Wage Phillips Curve. Frankfurt: ECB.

Papadamou S and Tzivinikos T (2017) The macroeconomic effects of fiscal consolidation policies in Greece. Journal of Financial Economic Policy 9(1), 34-49. doi: https://doi.org/10.1108/JFEP-07-2016-0051

Papadimos L (2011) Cyprus economic society. The sovereign debt crisis, financial stability and fiscal policy in the euro area. Ekonomia 14(2), 108-118. Retrieved from www.ekonomia.ucy.ac.cy/RePEc/ekn/ekonom/papers/01-11W.pdf

Passas C and Pierros C (2017) The Failure of Internal Devaluation and the Case of an Investment-led Strategy to Foster Competitiveness in Greece. Athens: Labour Institute GSEE.

Petroulakis F (2017) Internal Devaluation in Currency Unions: the Role of Trade Costs and Taxes. Frankfurt: ECB. Retrieved from www.ecb.europa.eu/pub/pdf/ scpwps/ecb.wp2049.en.pdf

Phillips A (1958) The relation between unemployment and the rate of change of money wage rates in the United Kingdom, 1861-1957. Economica 25(100), 283-299. doi: https://doi.org/10.1111/j.1468-0335.1958.tb00003.x

Prag J (1994) The response of interest rates to unemployment rate announcements: is there a natural rate of unemployment? Journal of Macroeconomics 16(1), 171184. doi: https://doi.org/10.1016/0164-0704(94)90050-7 
Rebitzer J (1988) Unemployment, labor relations, and unit labor costs. Unemployment, Labor Relations, and Unit Labor Costs 389-394.

Reinhart C and Rogoff K (2011) Growth in a Time of Debt. Massachusetts: NBER. Retrieved from www.nber.org/papers/w15639.pdf

Rodríguez C, Campello E, Varela-Candamio L and Pateiro-López C (2016) The behavior of the components of M3 in the euro area: 1999-2014. Open Journal of Business and Management 4(4), 606-620. doi: 10.4236/ojbm.2016.44062

Rostagno M, Altavilla C, Carboni G, Lemke W, Motto R, Guilhe A and Yiangou J (2019) $A$ Tale of Two Decades: the ECB's Monetary Policy at 20. Frankfurt: ECB. Retrieved from www.ecb.europa.eu/pub/pdf/scpwps/ecb.wp2346 dd78042370.en.pdf

Salop J and Spitäller E (1980) Why does the current account matter? Palgrave Macmillan Journals 27(1), 101-134. doi: 10.2307/3866863

Sangkuhl E (2015) How the macroeconomic theories of Keynes influenced the development of government economic finance policy after the great depression of the 1930s: using Australia as the example. Athens Journal of Law 1(1), 3252. doi: https://doi.org/10.30958/aj1.1.1.3

Schwarzer J (2013) Samuelson and Solow on the Phillips curve and the "Menu of Choice": a retrospective. OEconomia 3(3), 359-388. doi: 10.4000/oeconomia.138

Sousa R and Yetman J (2016) Inflation Expectations and Monetary Policy. Basel: BIS. Retrieved from www.bis.org/about/contact.htm

Stock J and Watson M (2007) Why has U.S. inflation become harder to forecast? Journal of Money, Credit and Banking 39(1), 3-33. doi: https://doi.org/10.1111/ j.1538-4616.2007.00014.x

Tobin J (1995) Inflation and unemployment. In Estrin S and Marin A (eds), Essential Readings in Economics. London: Palgrave, pp. 232-254. doi: https://doi.org/10. 1007/978-1-349-24002-9_12

Vamvakidis A (2015) ECB monetary policy and the euro during the crisis. In Thomakos D, Monokroussos $\mathrm{P}$ and Nikolopoulos $\mathrm{K}$ (eds), A Financial Crisis Manual. London: Palgrave Macmillan, pp. 39-57. doi: https://doi.org/10.1057/ 9781137448309_4

\section{About the Authors}

Panagiotis Liargovas is Jean Monnet Professor in 'European Integration and Policies' at the University of the Peloponnese as well as Head of the Centre of Planning and Economic Research (KEPE). Furthermore, he was Head of the Parliamentary Budget Office at the Hellenic Parliament. He received his BA degree from the University of Athens and his MA and PhD degrees in Economics from Clark University, Worcester, MA, USA. He has been a Fulbright Scholar, a Bakalas Foundation Scholar, a Teaching Assistant Scholar (Clark University) and a European Commission trainee (Brussels). He has taught in many Universities including Clark University, Bologna University, and the Universities of: Athens, Patras and Crete. His research agenda is highly interdisciplinary, combining economics, banking and finance, social issues and management, and it focuses mainly on two regions: the European Union and Southeast Europe (including Greece). 
Marios Psychalis holds a PhD in Economics from the University of Peloponnese, Department of Economics, while he holds an MA and an MSc from the University of Athens and Athens University of Economics and Business, and he has a Bachelor's Degree from the University of Athens. He graduated from the National School of Public Administration, and has work experience in both private and public sectors. His academic interests are at the fields of macroeconomics, public debt, EMU integration and economic policy. He has published papers related to fiscal policy in the EMU and public budgetary frameworks. 